\title{
Rebalancing the Global Economy
}

\author{
Stefan Collignon
}

\begin{abstract}
Imbalances are a dominant feature of the world economy, and it has been argued that they have contributed to the Global Financial Crisis. A revaluation of the Chinese currency has often been recommended to reduce the current account imbalance between USA and China. This paper will argue that emerging Asia's current account surpluses are a necessary condition for rapid catch-up growth and should not be eliminated soon; instead the excessive dollar-bias in Asian holdings of external claims needs to be reduced, because the problem behind the recent crisis was that emerging economies have placed their foreign exchange reserves nearly exclusively in USD assets and have neglected alternatives assets like euro and the yen. A policy proposal for a common Asian peg to a basket of euro and yen is made.
\end{abstract}

23.9.2010 


\title{
Rebalancing the Global Economy
}

\author{
Stefan Collignon ${ }^{1}$
}

A global economy needs global management. This is the lesson of the Global Financial Crisis. When policy makers set up the G20, they seemed to have understood, but very quickly this new global economic government got stuck in the gridlock of international bureaucracy. Banal and dry Communiqués are usually a sure sign that governments cannot agree on substance because partial interests block progress to the common good. Regarding monetary issues and global imbalances, America and Europe are at loggerheads with China and Asia, because they ask for exchange rate policies that would undermine the success of the Asian development model. Under these conditions, global policy cooperation is impossible. This paper presents a new approach to an old problem and it shows how making use of the euro could contribute to a win-win solution for the global economy.

Imbalances are today a dominant feature of the world economy, but there is no agreement whether they are harmful or not. For some economists, they are unsustainable and have contributed to the Global Financial Crisis; ${ }^{2}$ for others they are the unintended consequence of otherwise desirable developments. ${ }^{3}$ Unless these opposing views are brought together, managing the global economy will remain an empty wish.

There is little doubt, however, that high savings and the accumulation of foreign exchange reserves by Asian Central banks have fuelled the domestic American credit boom, which has now collapsed. As history teaches, the larger the bubble, the harder the fall. Ignoring global imbalances is, therefore, irresponsible. While it is true that the US current account deficits have narrowed recently, the system that has generated them has not changed. We need to understand, why this is so and what can be done about it.

Bernanke (2005) first advanced the thesis that the world experienced a "Global Savings Glut", which kept long term interest rates down, fuelled capital gains and allowed American households to reduce their savings. He only missed mentioning that it could lead to an unsustainable asset bubble. Most of the Global Savings Glut originated in Asia and in particular in China. Asian savers lent money to American consumers who then spent it on cheap goods from Asia and seemingly ever-appreciating domestic assets. While evidence confirms the symbiotic relation between the United States and Asian economies, the Global Savings Glut hypothesis portrays America as the victim of excessive capital inflows, which were pumped into the US because American asset markets were highly efficient and the US dollar attractive. The villains in their story are Asian savers who do not know what else to do with their savings but to keep them in dollar assets. The resulting policy recommendation is simple: if

\footnotetext{
${ }^{1}$ Professor at S. Anna School of Advanced Studies, Pisa and fellow of Global Governance Centre at LSE. I am grateful for research assistance from Centro Europa Ricerche (CER), Rome, notably Lory Barile and Alessandro Carettoni. This paper is part of a larger transcontinental research project on global imbalances funded by Bertelsmann Foundation.

2 Obstfeld and Rogoff, 2009.

3 See Cooper 2010, Doooley, Folkerts-Landau and Garber 2003; 2007. For a more nuanced view see Eichengreen 2007.
} 
excessive savings and current account surpluses have caused the crisis, Asia's development model must change. Undervalued currencies should appreciate to make US imports more expensive and balance current accounts while Asian governments should focus on expanding domestic consumption. This is the policy consensus shared by policy makers in Washington, Europe and major international organizations.

By contrast, this paper will argue that emerging Asia's current account surpluses are a necessary condition for rapid catch-up growth and should not be eliminated soon; ${ }^{4}$ instead the excessive dollar bias in Asian holdings of external claims needs to be reduced, because the problem behind the recent crisis was that emerging economies have placed their foreign exchange reserves nearly exclusively in USD assets and have neglected alternatives assets like euro and the yen. This investment strategy has fuelled the rise in American asset prices to a point where it became unsustainable. However, the dollar is no longer the world's only possible reserve asset. The euro exists. If Asia has invested most of its reserves in dollars, the reason is that the exchange rate peg has given protection against uncertainty, and central banks need dollars to maintain the dollar peg. Rebalancing the global economy requires, therefore, reviewing Asia's currency pegs. Europe and Japan could play a more important role in absorbing emerging Asia's surpluses and greater diversification of financial investments could stabilize the global economy.

The paper will first look at the facts behind global imbalances, then analyze the transformation in the world economy that has contributed to this development and conclude on an economic strategy that offers a win-win solution for Asia, America and Europe.

\section{Assessing Global Imbalances}

Let us first clarify the notion of global imbalance. It has three dimensions: current accounts, the capital balance and changes in reserve assets. First, the current account deficit of a country is the difference between domestic investment and savings. In a closed economy, investment is always equal to savings, because investment will generate income until savings match the initial investment. In an open economy, the difference between investment and domestic savings can be financed by borrowing savings from another country. Thus, the equality will only hold at the world level and this is why global balances sum up to zero. Yet, given that savings are the excess of income over consumption, and that a "country" is economically defined by its currency, ${ }^{5}$ a country can only borrow

\footnotetext{
${ }^{4}$ Catch-up growth implies wealth creation by the rapid accumulation of capital, which consists of domestic investment and the accumulation of foreign assets. As I will argue below, an undervalued currency creates the conditions for attractive locations for private investment and foreign reserve accumulation by central banks does the rest. If imports are part of consumed income, they reduce savings and therefore the accumulation of wealth, but if they are part of domestic investment, this must be qualified. Korea and Taiwan may be examples that export-led growth can go through periods of current account deficits due to importing materials and capital goods.

${ }^{5}$ The only economically meaningful definition of a country is that it is a payment union where no foreign reserves are needed for making payments. The world under the gold standard, or dollarized economies, are therefore not "economic countries", because they cannot issue base money as the accepted reserve asset for the domestic payment system. The Euro Area, however, is a "country" in the economic sense, with individual
} 
from another, if the lender is able to sell goods and services to the borrower and is willing to hold the claim on the debtor in foreign currency. ${ }^{6}$ What one country borrows is necessarily the surplus of another. In other words, consumption in the US can be "excessive" and domestic saving can be low, because American financial markets are attractive for Chinese investors and Chinese products are cheap for American consumers. Hence, the current account deficit signifies an excess of spending over domestic production, or a higher rate of investment than can be financed by domestic savings, or that owners of wealth claims in surplus countries are willing to hold assets denominated in the currency of the deficit country. These are three aspects of the same phenomenon.

Second, the capital balance. It is directly linked to changes in reserve assets. Capital flows caused by the private sector are recorded in the capital balance; those, which depend on policy decisions, are recorded as changes in foreign exchange reserves of the central bank. If a country imports more than it exports, it needs foreign currency to pay for it. It can borrow and/or run down foreign reserves. Conversely, an export surplus implies lending money to consumers abroad and/or accumulating foreign reserves by the central bank. If more capital flows into (or out of) a country than it wants to borrow (or lend), the central bank must buy up these foreign currencies (or sell them) and accumulate them in the form of foreign exchange reserves if it wants to keep exchange rates stable. Unless the net inflows of capital are bought by the central bank, the currency will appreciate. However, net capital outflows can only temporarily be compensated by drawing on reserves, because sooner or later authorities will run out of reserves. This happened to many Asian countries during the Asian crisis. There is therefore an asymmetry between strong and weak currencies. The central bank in an economy with a strong currency always has the choice between accumulating foreign exchange reserves and letting the exchange rate appreciate. For weak currencies, the loss of reserves invariably ends up with exchange rate depreciation.

Because trade imbalances are always balanced by corresponding capital flows, the real economy and the financial sphere are simply mirror images. If current account balances are financed by private capital flows and leave official reserves unchanged, we will call this weak imbalance. A stronger condition for global balance would imply stationary current accounts for all regions and countries, and equally balanced capital account, so that the shares in global foreign exchange reserves do not reveal trends for structural change. ${ }^{7}$ Weak imbalances can be sustainable for a significant period of time and can be justified by intertemporal trade. Strong imbalances are unsustainable.

The system is stable as long as trade and financial strategies are complementary, but it will crash when the portfolio preferences for goods and services and financial wealth become inconsistent. Such crash

member states being economic provinces. The reason is, of course, that Euro Area member states get money from the ECB and not from using foreign exchange reserves when they borrow from other member states. Germany's or the Netherland's current account surpluses are internationally only relevant insofar as they contribute to the overall reserve position of the Euro Area. I thank Richard Cooper for pushing me to clarify this point.

${ }^{6}$ Strictly speaking, the current account balance includes the claims on returns from foreign investment. In Japan this is an important part of the current account surplus.

${ }^{7}$ I interpret the stochastic noise around the mean as manifestations of intertemporal trade. Unit root tests for the current account data in figure 2 all reject the assumption of stationarity. 
can take the form of exchange crisis, like in Asia in the late 1990s, or distort asset prices as in the United States during the 2000s. Hence, the flows recorded in the current account and the capital balance must be consistent with the portfolio preferences of private assets holders and public authorities. Otherwise a crisis will occur that will dramatically revalue exchange rates and/or asset prices.

After these conceptual clarifications, we now look at the facts and start with current accounts. For over a decade, the United States has accumulated massive current account deficits, while Asia has produced surpluses and the Euro Area has stayed roughly in balance. See Figure 1. China's economic success is based on the export-led development strategy which had proven already highly successful in Japan after the war and later in the so-called emerging "Asian Tiger" economies during the 1980 and 90s. America borrowed what Asia lent. ${ }^{8}$ Until 1998 the biggest lender was Japan; despite large fluctuations, Chinese current accounts were structurally balanced in the 1980 s and only moved to a permanent surplus, after China joined WTO.

\section{Figure 1.}

Current Account Balances as Percent of GDP

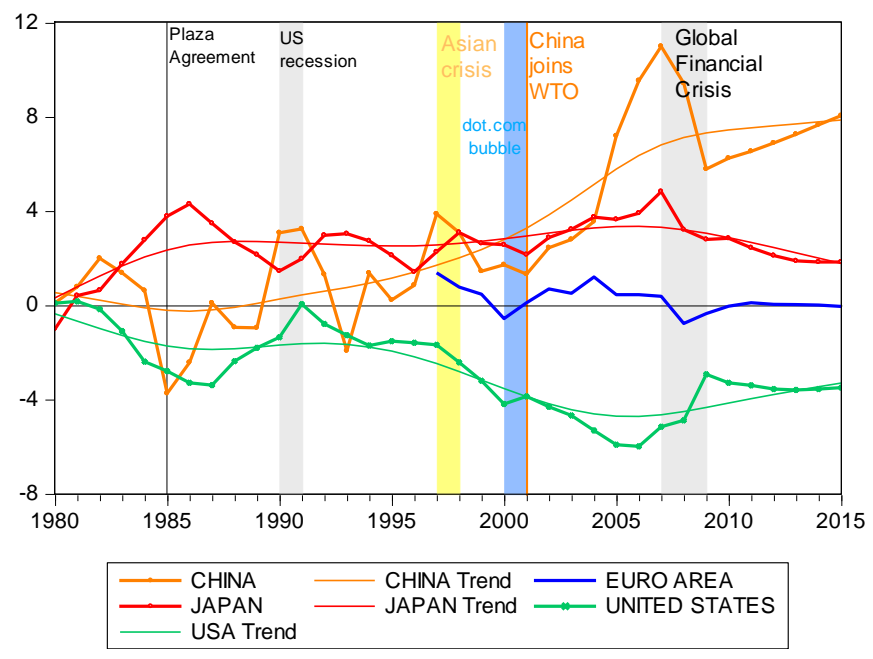

While Figure 2 concentrates on the four largest economies, Figure 2 shows the current account balances for emerging Asia and Korea. As a result of the currency depreciations in the crisis, which were less important in the Chinese World (PR China, Taiwan, Singapore), current account balances have improved everywhere in Asia.

\footnotetext{
${ }^{8}$ During the Bush presidency this pattern changed slightly. The United States did not only borrow from Asia, and increasingly from China, but also from Europe and the Middle East. This excess has now been corrected.
} 
Figure 2.
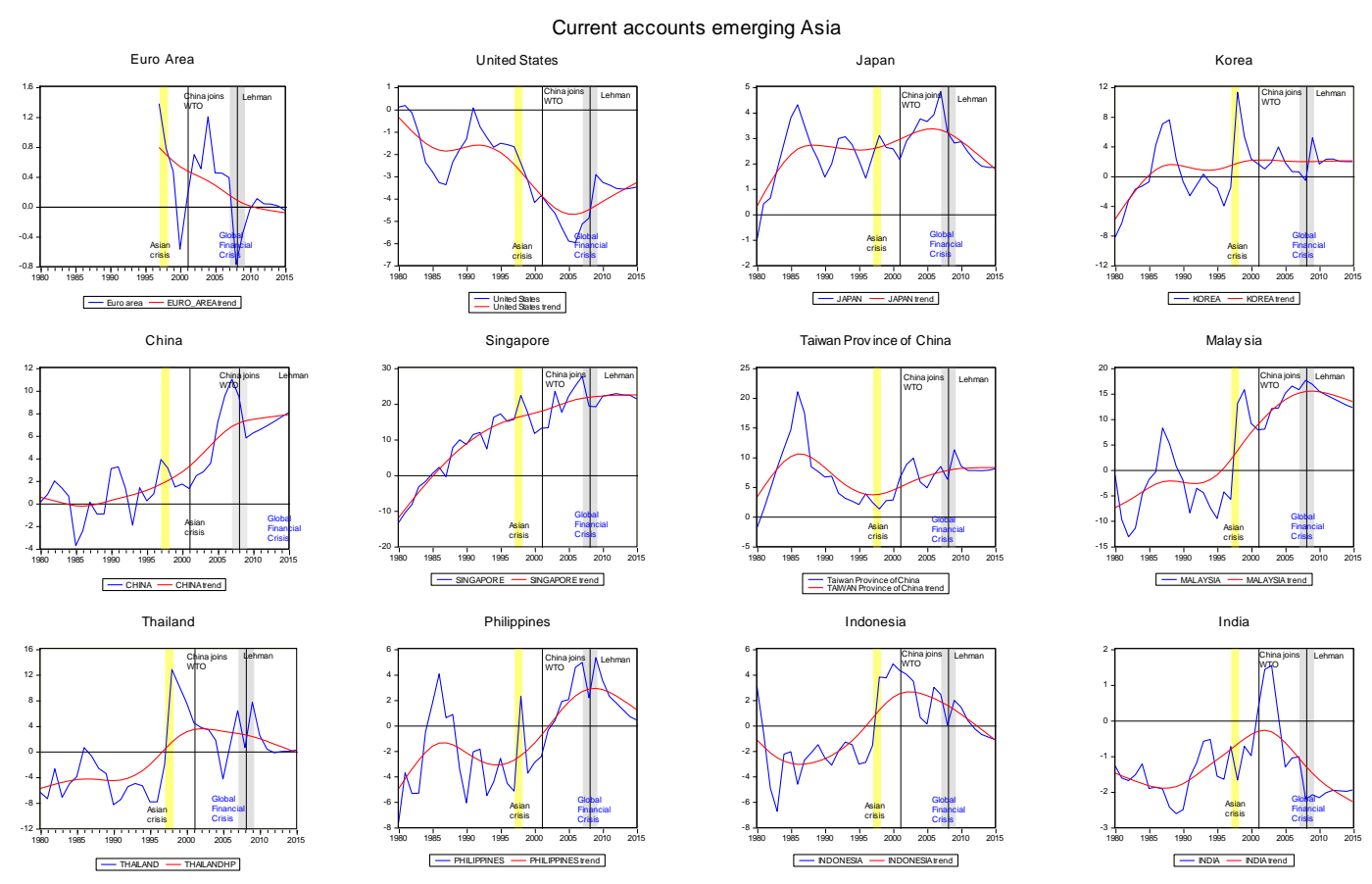

As monetary policy tightened world-wide in 2006 and 2007, there has been a slow trend ${ }^{9}$ for current account imbalances to diminish, especially in Japan and the USA, but also in the rest of Asia, most markedly in India. This development was temporarily accelerated by the financial crisis, which has imposed sharp corrections on the United States, Japan and China. However, even if there is now a tendency to revert to equilibrium in Japan and the US (the trend lines converge slowly to zero), the issue of global imbalances is not going away soon, mainly because of China. The IMF (2009) still expects the American external deficit to hover around $2.5 \%$ in 2014, Japan to maintain a structural surplus, and China will increase its surplus well above $8 \%$. It is not clear, who will absorb these rising Chinese surpluses. These figures show that global imbalances in the strong sense exist and are not just a passing phenomenon that is automatically remedied by forced adjustment following the Global Financial Crisis. Yet, it remains unclear what drives them and what policies are required to avoid global balances from becoming harmful.

Global imbalances in the strong sense show up in the distribution of foreign exchange reserves and confirm the structural imbalance in the global economy. The total volume of reserves has more than doubled relative to world GDP in the last decade, from 5.7\% in 1999 to $13 \% 2009$. Figure 3 shows the share of foreign exchange reserves held by some significant countries or groups of countries. The dominant feature is the rise of the share of emerging and developing countries and the relative fall in advanced economies.

${ }^{9}$ The trends were calculated by the Hodrick-Precott filter. 
Figure 3.
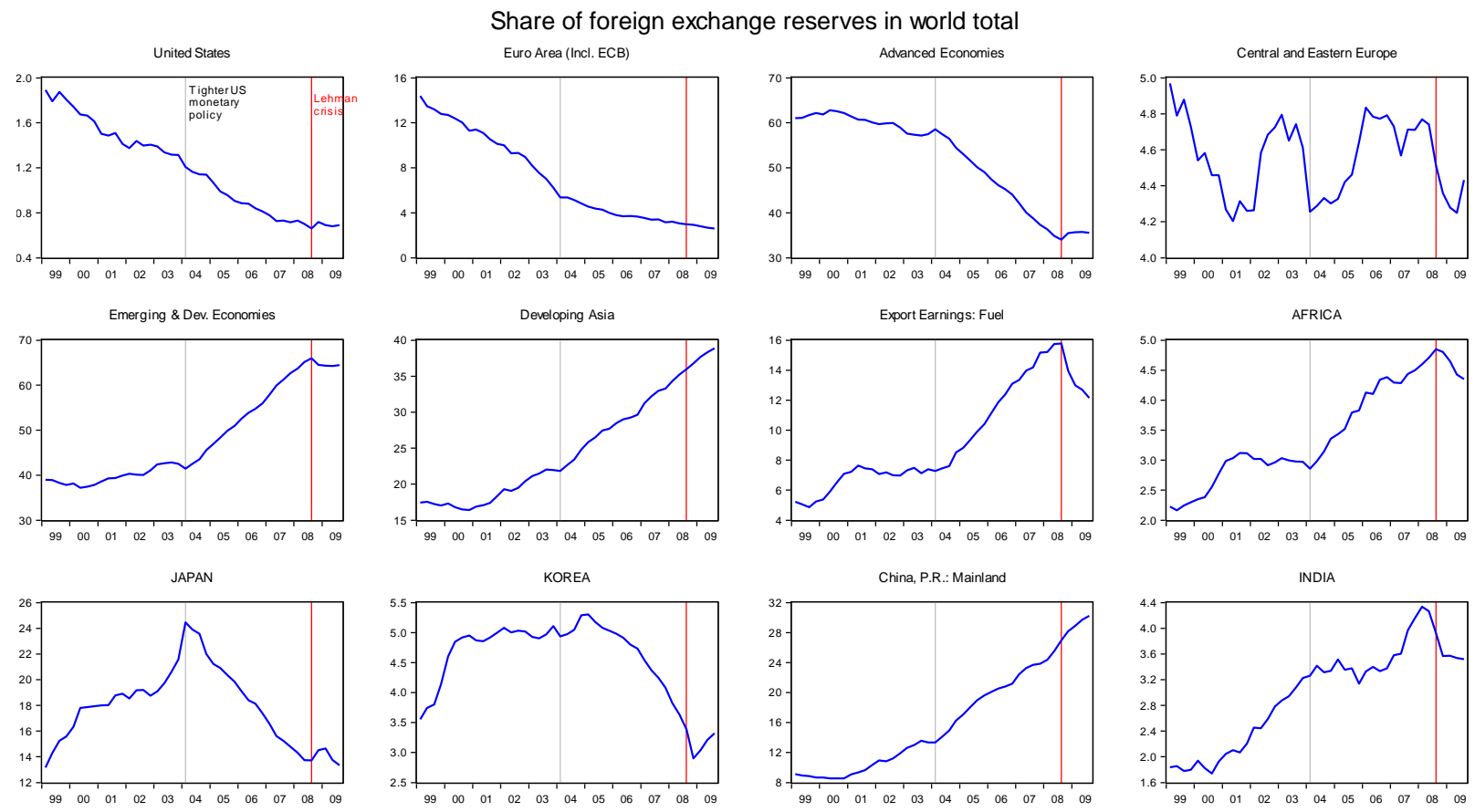

The first quarter 2004 marks a break in the trends of several countries. Advanced economies saw their share fall significantly, with Japan reducing it by 10 percentage points, Korea and the Euro Area losing about 2.5 points each. By contrast, fuel exporting countries, Africa and developing countries generally accumulated reserves. This break coincides with the tightening period in US monetary policy. Between March 2004 and June 2006 the Fed increased short term interest rates from 1.1\% to 5.5\%. It is possible that these higher returns have attracted short term investment from developing central banks, which was then transformed into longer maturities by American banks. This might have caused the Greenspan "conundrum", whereby higher fed fund rates did not raise long term interest rates in the United States. However, for our purposes the most interesting observation is the fact that developing Asia, and especially China, followed an unbroken tendency of accumulating foreign exchange reserves faster than the rest of the world. This is a clear indication that Asian emerging economies are pursuing deliberately a strategy of undervaluing their exchange rates by accumulating foreign exchange reserves, and this strategy causes global imbalances in the strong sense.

The reserve accumulation by developing Asia can be seen as proof for "manipulating" exchange rates. For years economists had been arguing that this situation was not sustainable and will cause a large depreciation of the USD. ${ }^{10}$ However, this did not happen. According to neoclassical economists, the lasting disequilibria are an abnormality. Government interventions must have distorted the market mechanism and the imbalances must therefore be remedied by appreciating local currencies. If currencies were allowed to float and markets worked perfectly, they argue, and the world should very

${ }^{10}$ Obstfeld, 2005; Lane and Milesi-Ferretti 2007; For a more nuanced view before the crisis see Eichengreen, 2007 
rapidly return to equilibrium. Yet, the fact that this has not happened indicates that persistent distortions have their own logic. It is in fact possible, as Eichengreen (2007: 30) speculates, that the set of distortions which reduce welfare in the short term is offset by another set of distortions which increase it in the long run and that governments adopt development strategies for the long run. The most important policy instrument for causing these distortions is the exchange rate, because it sets the relative price of goods and services between economies and thereby generates competitive advantages and determines opportunities for profit making and incentives for the allocation of investment and wealth. We will now look at explanations why emerging economies have implemented exchange rate policies that have caused these persistent market distortions.

The undervaluation model

There are two models, both based on exchange rates, which can explain sustained global imbalances. A popular explanation for the large current account surpluses by emerging Asian economies is that their governments undervalue the exchange rate in order to be competitive in world markets. As Rodrik (1986) remarked, "a policy which deliberately maintains the exchange rate at a disequilibrium level can be welfare-increasing by promoting structural change." The classic examples for a systematic undervaluation strategy that supports rapid catch-up growth were Japan and Western Europe under Bretton Woods. Figure 4 shows that under the fixed exchange rate regime of Bretton Woods, unit labour costs in Japan and Europe remained stable at 40 to 66 percent of the American level. This strategy produced economic miracles. After Bretton Woods collapsed, exchange rates became flexible, European and Japanese unit labour costs rose 20 percent above the US-level and the miracles disappeared. Note that Japan has followed the USD more closely since the early 2000 s than in previous decades, although this did not reflect a pegging strategy in a strict sense, as will be shown below. As a consequence of the deflationary policies in Japan, unit labour costs have fallen over the last decade significantly, staying $30 \%$ below the US and nearly $50 \%$ below the Euro levels. Hence if emerging Asia is following a development strategy of systematic currency undervaluation, it can refer to highly successful precedents. The problem for the global economy is not so much that governments "manipulate" their currencies, but how they will exit the undervaluation strategy when they have sufficiently advanced in their catching-up process. 
Figure 4

Unit Labour Costs Relative to USA

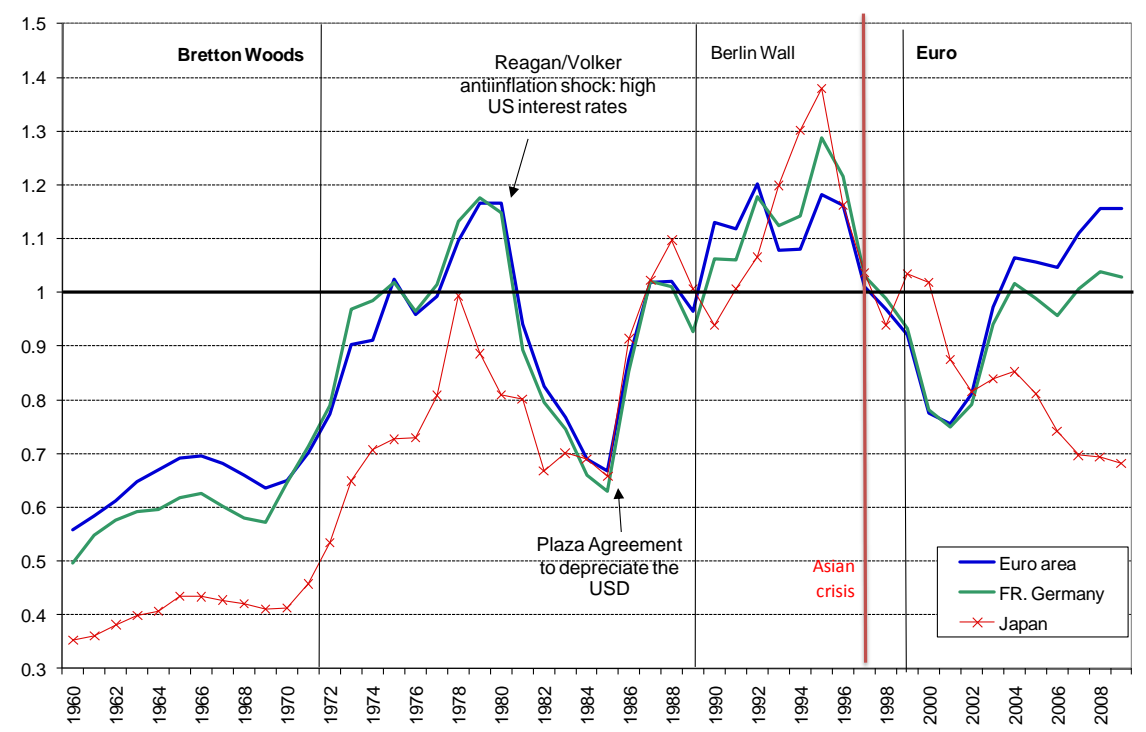

Dooley, Folkerts-Landau and Garber $(2003,2007)$ have argued that some essential features of the early Bretton Woods model are now reproduced by emerging Asia, and especially in China. ${ }^{11}$ According to this model of the international financial system, the world is divided into a core and a periphery. The core has efficient financial markets and a stable currency, which serves as the international reserve asset; the periphery, which starts out with low productivity and an underemployed labour force, seeks integration into the world market by export-led growth, because it generates employment and economies of scale. It also "develops" human capital through learning-by doing. However, the periphery does not have deep and fully developed financial markets and lacks the skills of investing local savings efficiently. For this reason, investors in the periphery prefer to keep their financial wealth in the hard currency of the centre and invite foreign investment to build up industry. The government assists this strategy initially by devaluing the currency and then by resisting its appreciation. The devaluation compensates for low productivity and other inefficiencies. The currency appreciation is avoided by accumulating foreign exchange reserves. Because the reserve accumulation could expand the central bank's balance sheet and the supply of base money, which could have inflationary consequences, the monetary effects of reserve accumulation are sterilized. On the other hand, when central banks in the periphery buy government securities in the centre, they generate seignorage gains for the centre, and if the centre does not sterilize the capital inflow and keeps interest rates low, ${ }^{12}$ growth is improved here, too.

The Dooley, Folkerts-Landau and Garber (2007: 107) model describes a transitory disequilibrium strategy, which has to meet the critical constraint that once the periphery has caught up with the

\footnotetext{
${ }^{11}$ For a critical review and the difference between the original Bretton Woods system and today's pegged exchange rates, see Eichengreen, 2007.

${ }^{12}$ The impact of monetary policy on long term interest rates may not be instantaneous if foreign investors buy up securities, as Greenspan's famous "conundrum” has shown.
} 
centre, the capital stock accumulated in the periphery should be capable of producing goods that are internationally competitive, when it is combined with domestic labour paid at the word real wage rate. If this constraint is met, currency undervaluation by the periphery can be beneficial for the world economy, even if it generates temporary, although persistent, imbalances.

\section{The volatility model}

The undervaluation strategy can take the form of fixed exchange rates if the government can control wages (as in China), or of crawling pegs that compensate for domestic inflation (as in the Philippines, India and Indonesia). However, the system needs the centre's currency as the anchor for its undervaluation strategy. A successful exchange rate strategy must peg local currencies to a leading world currency, because that guarantees the integration into a large and open market capable of absorbing imports from emerging competitive producers and offers deep and efficient financial markets.

Pegging exchange rates serves two purposes: it fixes relative price levels between two economies and it minimizes the uncertainty caused by rapid exchange rate fluctuations. Competitive and undervalued exchange rates are only a necessary, not a sufficient condition for rapid economic development. The profitable environment must be sustained. The more certain future returns are, the higher will be the rate of investment. By pegging to an anchor currency, governments reduce economic uncertainty in foreign transactions. This uncertainty created by volatile exchange rates works like a tax or tariff wedge between economies that requires higher returns on investment in order to attract capital into the domestic economy. This is true for FDI and portfolio investment in emerging economies, but it is also a barrier for foreign reserve management. The return on financial assets held for reserve purposes must be higher, if the exchange rate volatility between currencies is high, in order to compensate for the higher risk. As a consequence, a country pegging to a key currency, will keep its foreign exchange reserves in that currency.

Collignon $(1999,2003)$ has argued that the desire to lower exchange rate volatility and increase investment and growth has caused the emergence of a system of bloc floating after the demise of Bretton Woods in the early 1970s. In a system of bloc floating, local currencies have been pegged with fixed or crawling rates to an anchor currency. During the time of the European monetary system, either the USD or the deutschmark served as anchor. After the creation of the euro, a number of European countries within and outside the EU have reduced exchange volatility to the new currency, but most of Asia has remained on a dollar-standard, even after the Asian crisis. The yen has never become an anchor currency for Asia, despite its high significance for FDI in Asia (Collignon, 2006).

The upper panel in Figure 5 shows the daily exchange rates of the three freely floating exchange rates Euro, dollar, yen. An upward movement represents depreciation relative to the euro and of the yen relative to USD. We find long term trends of euro-weakness from the mid-1990s to the early 2000 s. After 2000, the euro had a tendency to appreciate against the dollar until the Global Financial Crisis hit. The euro appreciated even more relative to the yen, because relative to the USD the yen first depreciated rapidly and then kept more stable than in previous periods. The overall picture of these 
key currencies is one of instability over the short and long run. ${ }^{13}$ The lower panel shows the volatility trends. They were calculated by estimating a $\mathrm{GARCH}(1,1)$ model to determine the conditional variance in the daily exchange movements and then putting these values through a HP filter. From 1995 until 2000 and again after 2006, exchange rate volatility between the USD-euro rate had a trend to be lower than for either of the yen rates. Except for some short periods in 2002 and 2004-2005, the volatility of yen-USD was lower than yen-euro. This indicates that Japanese exchange rate policies have sought greater stability with the dollar bloc than the euro bloc.

\section{Figure 5.}
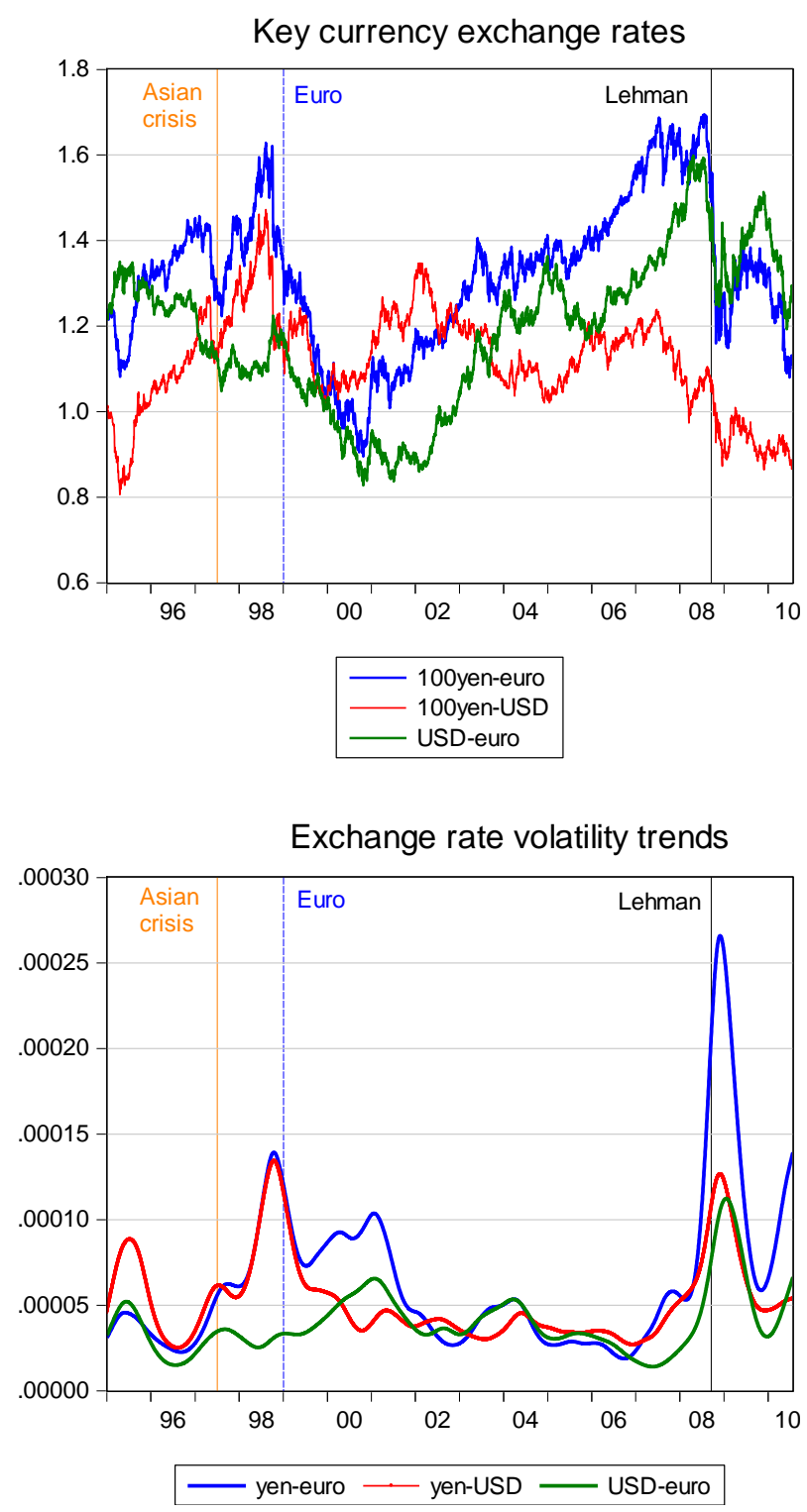

${ }^{13}$ Collignon 1996 presents a model where the volatility between key currencies has a tendency to increase with the size of the currency blocs. Collignon 2003 shows that the blocs are instable and collapse when the key currency appreciates too much. 
Figure 6 gives an overview of the exchange rates of Asian emerging economies relative to the US dollar, the euro and the yen. Not all of them have totally fixed their exchange rates, as China and Malaysia have. However, most of them have kept exchange rates to the dollar more stable than to the euro or the yen (see below). As a consequence of the dollar's weakness relative to the euro and Japan's shadowing of the dollar, Europe's currency appreciated against all of Asia including the yen. Because the yen has been less volatile relative to the USD since the euro was created in 1999, other Asians have also depreciated less against the yen. The broad picture is nominal exchange rate stability relative to the USD and an appreciating and volatile euro. Thus, the undervaluation of Asian currencies after the Asian crisis was reinforced by the dollar weakness, and the low volatility within the dollar bloc has supported Asian development, but marginalised Europe. 
Figure 6.

CHINA

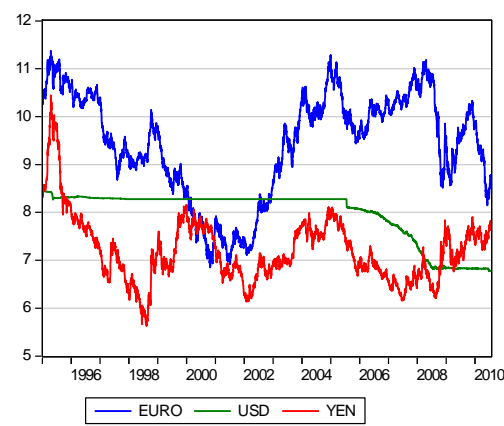

THAILAND

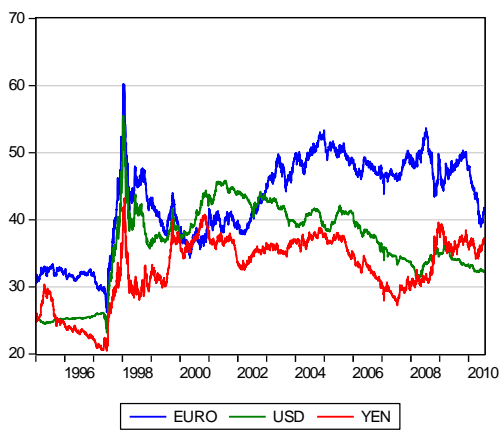

SINGAPORE

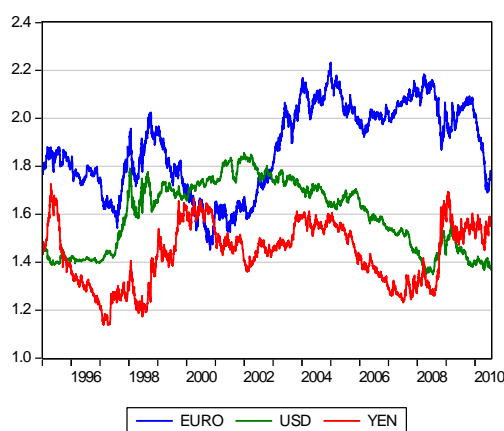

Emerging economies

INDIA

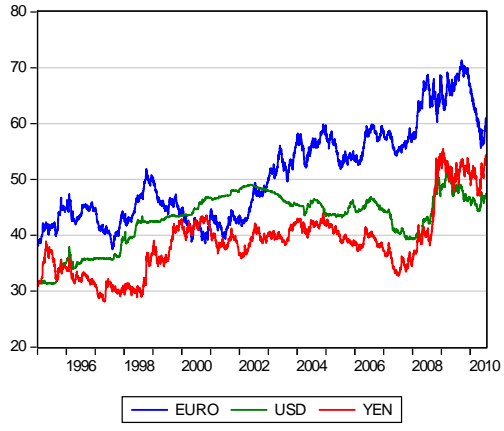

MALAYSIA

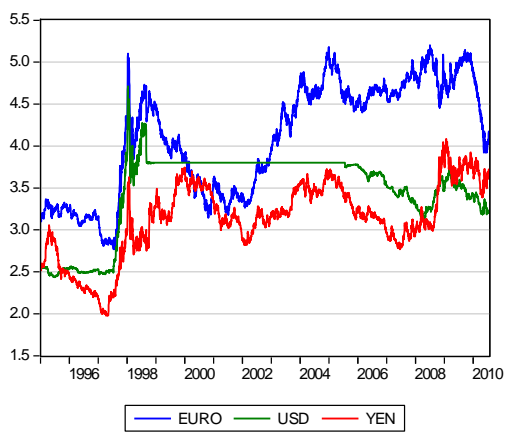

TAIWAN

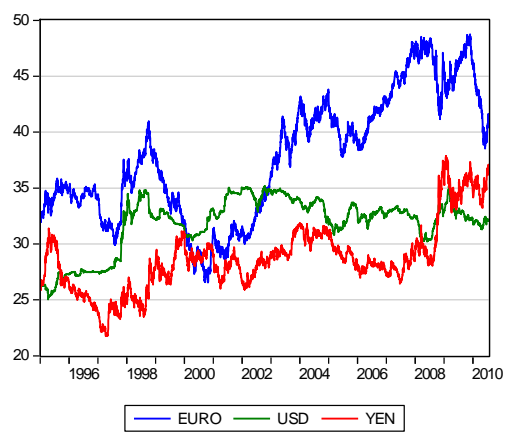

INDONESIA

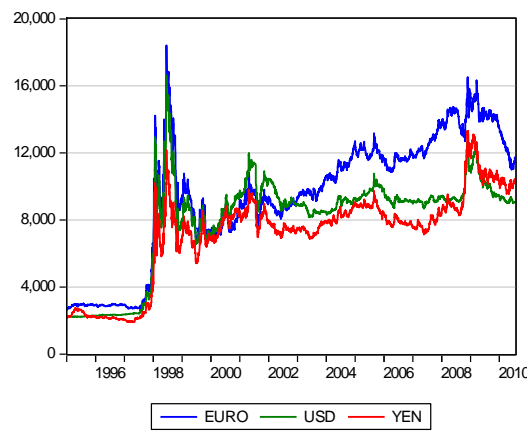

PHILIPPINES

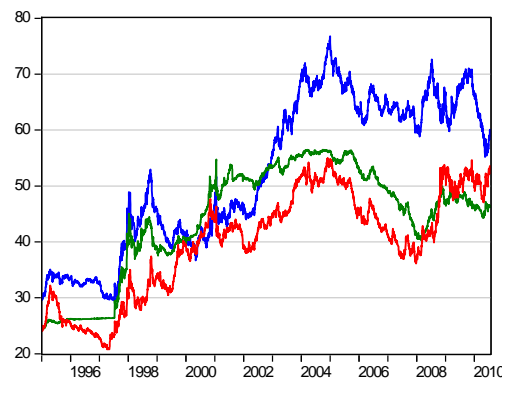

KOREA

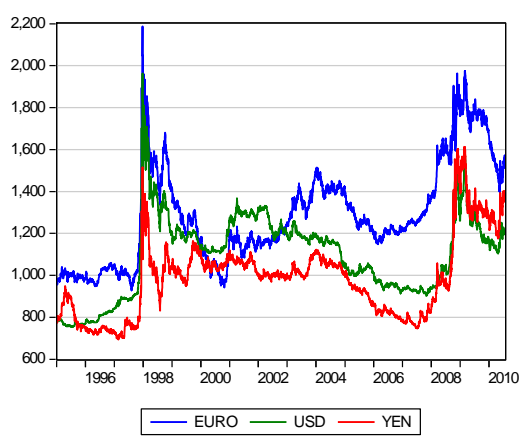

Figure 7 presents formal indicators for daily exchange rate volatility in Asia. It appears that for most Asian economies, volatility was higher for the euro (blue colour) and the yen (red colour) than for the US dollar (green colour). The Asian crisis in 1997 marked a period of significant devaluations and exchange rate volatility. However, subsequently all Asian currencies returned to a stable USD-peg: the volatility was clearly lower for the dollar than for the euro or the yen.

Figure 7. 
Exchange rate volatility trends

CHINA

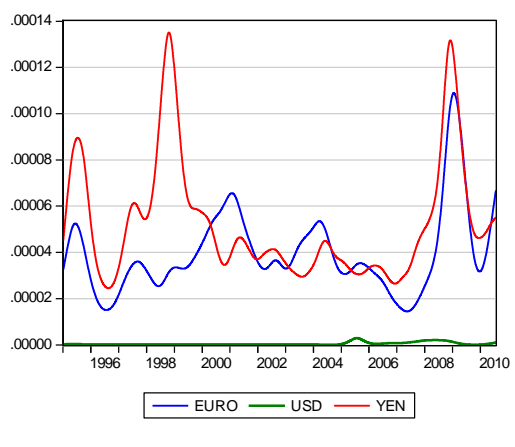

THAILAND

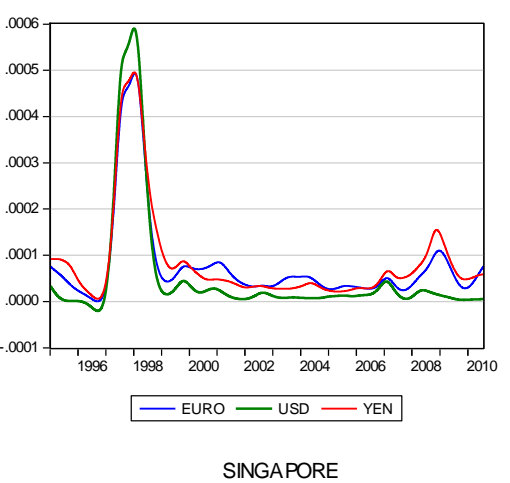

SINGAPORE

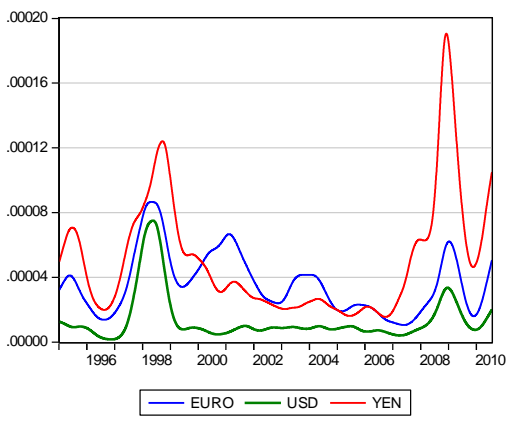

INDIA

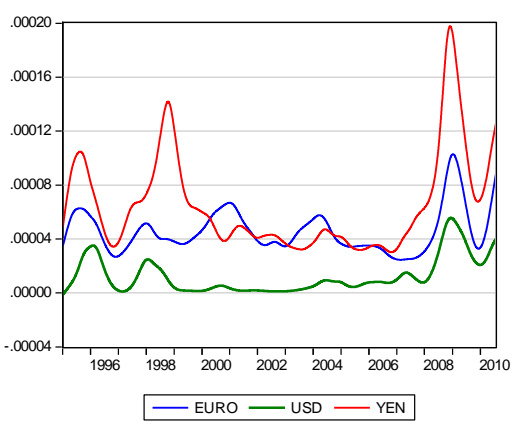

MALAYSIA

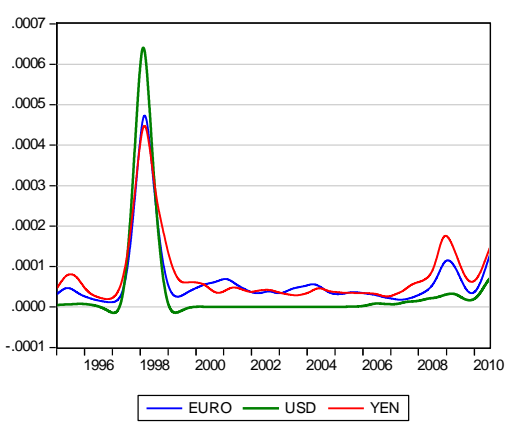

TAIWAN

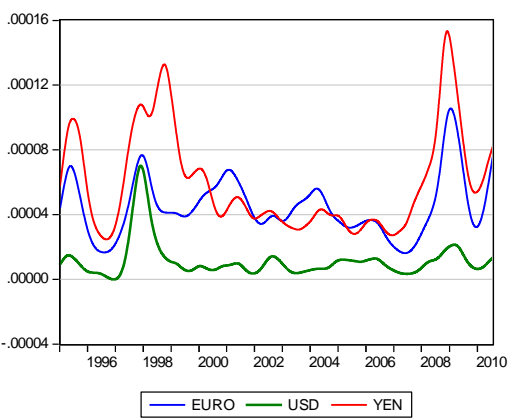

INDONESIA

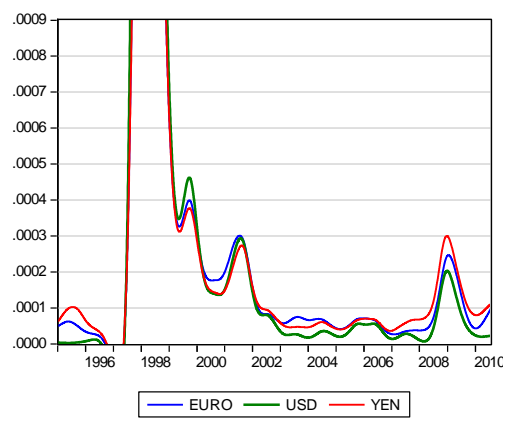

PHILIPPINES

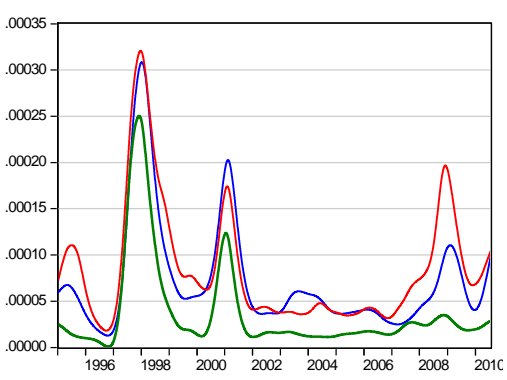

- EURO —USD —YEN

KOREA

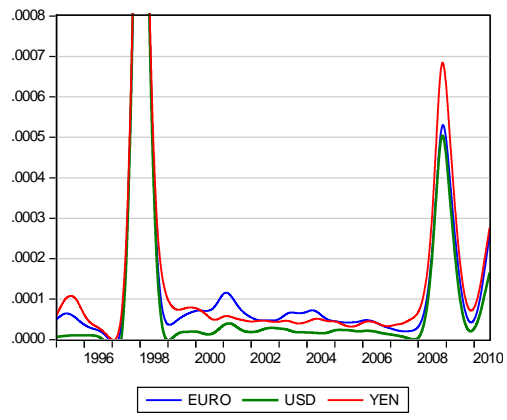

Thus, a clear picture emerges: Asia has pegged to the USD at competitive rates, which have generated current account surpluses and attracted capital flows, which were reinforced by the stable exchange rate environment. Governments have resisted the appreciation pressure resulting from capital inflows by accumulating reserves. This development model poses a problem to neoclassical economics: how was it possible that these distortions persisted for so long? The answer lies in the profound transformation of the global economy.

\section{The transformation of the global economy}

From a neoclassical point of view, the undervaluation of peripheral currencies is not sustainable, because it should lead to inflation, which will erode the competitive advantage. However, many Asian currencies have been able to sterilize the inflationary effects of reserve accumulation. If the centre economy would also sterilize the loss of reserves, it would cause slow growth at home. With modern 
financial systems, where central banks target consumer price stability, it is possible for the periphery to accumulate reserves and the centre to relax monetary policy as well, as long as inflation is kept at bay. The system of bloc floating generates a win-win structure for the centre and the periphery. The undervaluation of the periphery is beneficial for the centre, too, because imports from the periphery are cheap and competition restrains domestic inflation (Bean, 2006; Borio and Filardo, 2006; Tootell, 1998). Nevertheless, it also carries costs for the centre economy.

If the purpose of the undervaluation strategy is to integrate the underemployed labour force of the periphery into the global economy and to make it more efficient, it also causes fundamental restructuring of the labour force in the centre (Dooley, Folkerts-Landau and Garber, 2007). Hence the transformation of the global economy is not without social costs, and these costs must be balanced by economic benefits, which come from two sources. First, cheap imports increase real wages at the centre as the purchasing power of nominal income increases. This is potentially good for social stability, provided the gains are fairly shared; it also increases profits in the economy of the centre, and this is potentially good for investment, growth and employment. Second, because wages in the periphery are below the world equilibrium level and prices are competitive, inflation is contained in the centre. This makes it possible to relax monetary policy and thereby stimulate growth. This was the magic potion behind America's growth during the last decade. However, because consumer prices are kept down by cheap import competition, the excess liquidity will go into accelerated the asset price inflation.

Monetary policy in the United States prior of the Global Financial Crisi clearly underestimated this risk, but the alternative strategy of sterilizing the capital inflows might have been even worse, as it would have placed all the burden of the globalization process on the centre economy. Thus, it was the symbiotic relation between Asia and the United States, which made the costs of globalization socially acceptable, but outside the dollar bloc the effects were less benign. Asia benefited from the euro strength after 2000, but the social costs of restructuring the world economy were not compensated by capital inflows comparable to those of the United States. Nevertheless, the Euro Area did also benefit from cheap imports from Asia, which allowed the ECB to follow a more accommodating monetary policy. This was an improvement over the previous deutschmark bloc, where the Bundesbank needed to be excessively restrictive in order to generate the current account surpluses on which the anchor function of the DM rested. ${ }^{14}$ As a consequence, Europe's domestic dynamics has improved after the creation of the euro, but the social costs of globalization were higher than in the USA.

While it is true that all emerging economies in Asia pursued policies of export-led growth, the most fundamental transformation of the global economy is due to the integration of China into the world market. In 1980, China represented less than 1\% of World GDP. In 2010, it counted for 10\%, measured at market exchange rates. It has now more than four times the economic power of ASEAN or India and twice that of Germany. Asia as an economic region is now an equal partner in the world economy together with Europe and the United States. See Figure 8.

\footnotetext{
${ }^{14}$ For a formal model see Collignon, 2003.
} 
Figure 8.

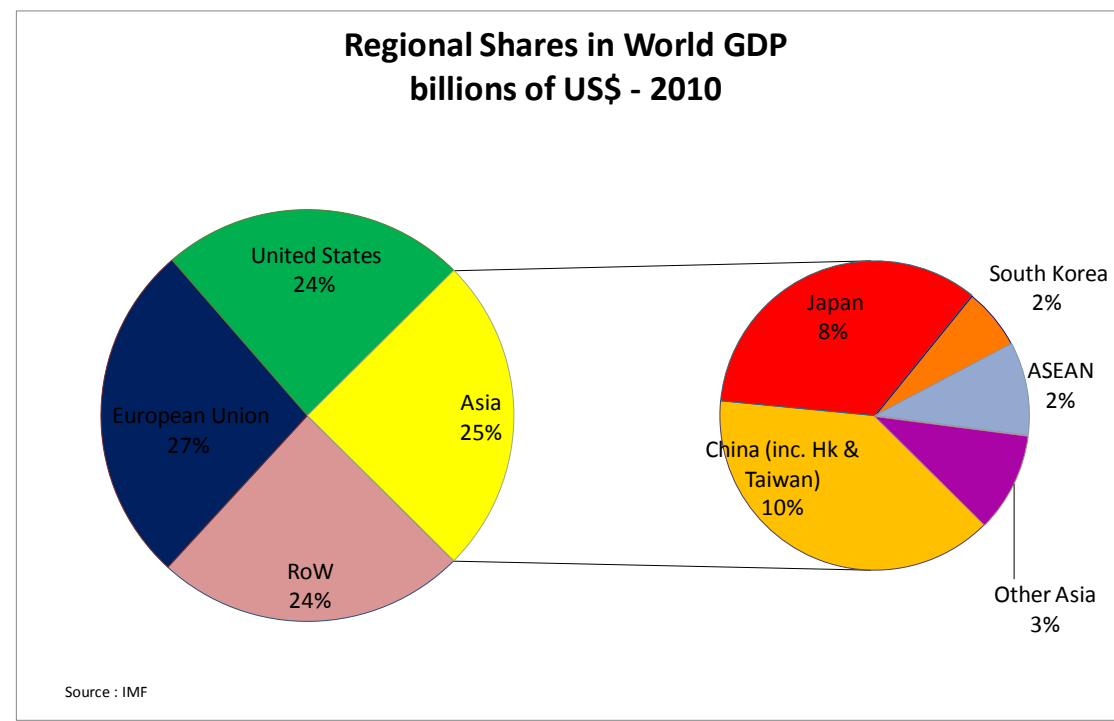

There is nothing unique, nor exceptional, about the rapid growth of the Chinese economy, which is simply following the well-established Asian model, based on high investment, quasi unlimited supply of labour, ${ }^{15}$ and fixed undervalued exchange rates. What is different with China is its size. Its population is $1.3 \mathrm{bn}$ today, i.e. over $20 \%$ of the world; China's labour force is 812.7 million, a quarter of the world's total. It used to increase by 10 million a year in the 1990s, but due to demographics this growth is slowing down. However, labour supply is even more strongly affected by the migration of an underemployed rural population moving at the rate of 20 million each year to industrializing coastal cities. Because the ITC revolution has lowered the cost of communication without having to move people, China's labour force has now effectively become part of the Western workforce through industries that export to the West. Thus, global labour supply has become highly elastic.

The integration of China and its labour force into the world economy was only possible because the export-led growth strategy combined competitive and stable exchange rates with long term wage stability. Unless exchange rates would have fixed competitive cost levels for exports, rapid economic growth would not have taken off. Without elastic labour supply, competitive wage costs would not be sustainable. And stability of exchange rates is necessary to ensure a framework of stable expectations and minimal uncertainty, without which investment would remain low. Dooley, Folkerts-Landau and Garber (2007) are right to emphasise that this development strategy has a transitory character and considering Chinese labour market dynamics, one will come to the conclusion that this transition will not be over for another decade or two. ${ }^{16}$

The competitive currency peg also explains why savings rates are so high in China and why they are invested in the United States: the undervaluation generates high profits, the low volatility makes

\footnotetext{
${ }^{15}$ The benchmark model is Lewis, 1954

${ }^{16}$ To be precise: given today's per capita income of USD 6200 in China and USD 28800 in the EU, and assuming China grows at an average rate of $7 \%$ and the European Union at $2.5 \%$, it will take 35 years until per capita income in the two countries will be equal.
} 
investment in the centre safe. Chinese savings consist largely of retained profits, especially in the State Owned Corporate sector. In fact, Chinese households' savings are not particularly excessive. ${ }^{17}$ The household savings rate, as a percent of GDP, fluctuates between 15 and 20 percent, while the overall gross savings rate is close to or above $50 \%$. To a small extent, the difference is explained by government savings (5\%), but the largest part, with about half of the total, is corporate savings. This is not surprising, given that high profits imply low real wages. In-depth analysis shows that these savings come essentially from retained earnings, which are reinvested by firms in fixed or financial assets, because the Chinese government does not have a well-defined dividend policy for state-owned companies (Anderson, 2008). Hence the competitive level of the yuan's exchange rate ${ }^{18}$ is a crucial driver for China' rapid economic growth, but it also generates the excess savings, which until now have been placed largely in the United States.

This dual effect constrains Chinese policy options severely. A shift from exports to domestic consumption, which is recommended by those who think China should concentrate on its domestic market, or a less competitive exchange rate, which is the aim of Western pressures on Chinese authorities, would lower the rate of capital accumulation and economic growth. No wonder exchange rate policies are so controversial. For, while the United States and Europe push China to revalue its currency, Chinese authorities know that the appreciation could ruin the model, on which their development depends.

This development has generated opportunities for some, and painful losses for others. In one generation, China's growth has lifted 500 million people out of poverty and the poverty rate has declined from $64 \%$ at the beginning of reform to $10 \%$ in 2004 . In advanced industrial countries, however, it has contributed to regional and sectoral deindustrialisation, higher unemployment and stagnant wages. With globalization, open markets, and highly elastic labour supply, the world has become richer, but also more complex, and harder to govern. After the Global Financial Crisis, the task must be to rebalance the benefits and burdens of globalisation between Asia, America and Europe.

\section{Regional integration and Asia's fixed exchange rate regime}

The Asian development model with fixed exchange rates has two further important and unintended consequences for the global economy. First, the common peg to the US Dollar has rendered exchange rates between East Asian currencies more stable. It has reduced uncertainty not only between Asia and America, but also within the East Asian region and this is a condition for the region's integration into the global economy (Kawai, 2010). Regional integration is therefore increasingly driving economic growth in the region and both depend on exchange stability in the region. Any policy proposal dealing with global imbalances must, therefore, look at emerging Asia as a whole and not only at China.

Secondly, the Asian choice of linking their currencies to the US economy has far-reaching implications for Europe, too. Given that the dollar-euro exchange rate is highly volatile, Asian currencies move with

\footnotetext{
${ }^{17}$ As Anderson (2008) shows, the widely believed argument, whereby Chinese households save massively because reform policies have dismantled the old communist welfare system, does not stand up to scrutiny.

${ }^{18}$ There are two names for the Chinese currency, the casual yuan and the official Renminbi (RMB). We will stick here to yuan.
} 
the dollar against the euro. Exchange rates between Asia and Europe are therefore less predictable than they are with respect to the dollar. This heightened uncertainty drives a wedge between Europe and Asia; it deters trade and investment and isolates the two continents. The exchange rate stability within the dollar zone privileges trans-pacific financial flows, so that Asian surpluses finance US deficits. Because the higher exchange rate volatility acts like a tariff or tax wedge, the trade volume between Europe and Asia is lower and financial flows do not stimulate European growth and demand for Asian imports. Thus, the symbiotic relation between Asia and America is determined by the exchange rate regime and structures trade flows

These two tendencies, namely regional integration in East Asia and the exclusion of Europe, make the correction of global imbalances difficult as long as the dollar remains the privileged reference currency for Asia. To sustain its development model, Asia needs to generate current account surpluses to keep high profits and accelerated capital accumulation going. If the dollar remains the reference currency, the United States will have to continue to buy cheap goods from Asia. Yet, if the American external balance is to come closer to equilibrium and the USD cannot be adjusted vis à vis Asia, the USA will be forced to generate trade surpluses with Europe and the rest of the world and this is only possible, if the dollar depreciates considerably against the euro and/or if European consumption and growth improve substantially. However, European consumption is unlikely to accelerate significantly, as long as financial flows from Asia are deterred from European financial markets by high volatility and finance essentially American consumption. The world is therefore caught in a dilemma. If the "old world" in the West imposes an appreciation on China, the "new world" in Asia would lose momentum and could disintegrate; but if the present system does not change, imbalances will continue and Europe could disintegrate under the pressure of global adjustment. We will now consider an alternative solution.

\section{Opportunities for monetary cooperation between Europe and Asia.}

\section{China bashing}

Fuzzy thinking has led European policy makers to follow Americans in pressuring China to revalue. Chinese authorities have resisted them, although some moderate face-saving concessions were made (see Figures 6 and 7). European and American policy makers should think again. Complaints about China's exchange rate regime are expressions of protectionism: firms denounce unfair competition, because they wish to keep cheap imports out of the European market; trade unions lament the loss of jobs, but rarely talk about the potential for job creation. They ignore that cheap consumer imports increase the purchasing power of wages. This is not to say that unfair trade practices are justifiable. Insisting on strict social standards should be part of Europe's leadership in the global economy. It would help emerging economies to improve their own standards of living. Yet, unless Europeans (and Americans) understand that Chinese authorities have good reasons for keeping their exchange rates fixed at competitive levels and deal with it intelligently, the dialogue with China will go nowhere and global imbalances will persist. Asia is the EU's most important growth market and sustained and rapid 
economic growth in China serves Europe's interest. A reform of the international exchange regime must respect China's strategic objectives as well as those of Europe, Japan and the United States.

Hence, a different strategy is needed; a win-win strategy, where Americans switch demand from foreign to domestic production in order to reduce unemployment after the Global Financial Crisis, lower their current account deficit and restore trust and confidence in America's leadership. Asia must continue to generate export surpluses, which are the foundation for their catching up process to higher living standards. As mentioned above, it will take several decades until this will change. For Europeans, it is crucial that the global adjustment will not take place at their expense. These are the objectives. They assign a role to exchange rate policies.

\section{A Euro-Asian cooperation proposal}

In the benign macroeconomic environment of the euro's first decade, European policy makers have concentrated on their domestic agenda: price stability, fiscal consolidation, structural reforms. National governments have been more concerned with protecting narrow domestic advantages than with improving opportunities for the European economy as a whole. After the Global financial Crisis, there is a need for a global strategy. Here is a five point plan of what could be done.

1. First, one must open the symbiotic relation between the United States and Asia. While Asia is to remain a net exporter for years to come, America cannot remain the consumer of last resort in the world. Hence, the European Union and Japan must take up some, but not all, of the global demand for products from Asia. The three main players could agree on a target for each of their economies to run a current account deficit of $1 \%$ of GDP. This would reduce absorption from the USA relative to 2009 by USD 226bn, but improve demand from the Euro Area by USD $40 \mathrm{bn}$ and from Japan by USD 147bn. The major burden of adjustment would be on Japan. A fairer deal would therefore set a deficit of $1.5 \%$ for the Euro Area. These targets would redistribute the American deficit, but they would hardly generate additional demand for Asian products. This must come from growth in the three advanced industrial economies and from the rest of the world.

2. The redistribution of current account deficits requires a change in relative prices, i.e. in exchange rates, and also domestic policies that stimulate demand in Europe and Japan. The dollar has to depreciate relative to Asian currencies; the euro and yen need to appreciate. However, as we have discussed, exchange rate stability, i.e. low volatility, can support the redirection of trade and investment by reducing uncertainty. Such support is especially warranted, if Europe is to accept an appreciation relative to Asian currencies. Several policy options may be considered. First, East Asian countries may simply re-peg from the dollar to the euro. This would generate monetary stability between Asia and Europe and give the US economy the necessary flexibility to adjust its current account deficit. However, if the Japanese yen remained freely floating, this measure could disturb investment flows between East Asia and Japan and affect growth negatively. Therefore, Japan must be part of any new monetary arrangement in Asia. A second option consists in pegging East Asian currencies, including the Chinese yuan, to a basket that contains large portions of Japanese yen and euros. Simultaneously the Bank of Japan and the European Central Bank would establish close cooperation with the purpose of minimizing volatility between their two currencies. This stabilizes the conditions for Japanese FDI into East Asia and the trade relations 
with Europe. The Japanese and European economy together represent a viable and attractive alternative to the symbiotic relation with the USA. These measures would not restore global balances in the strong sense, but they would narrow the size of imbalances.

3. Monetary authorities in East Asian countries will gradually increase reserve holdings in euro and yen. Thus, in the interest of expert-led catch-up growth in Asia, global imbalances in the weak sense would also be maintained for a limited, transitory, but significant period of time. Although there is no logical link between pegging and reserve holdings (Obstfeld and Rogoff, 2009), the practical reasons for doing so are strong, because liquidity requirements for market interventions will increase demand for holding anchor currencies. To see this, imagine a speculative attack against a country, which has pegged against the euro but keeps foreign exchange reserves in dollars. If the dollar is weak at this very moment, the mobilization of reserves to defend the europeg would be more costly. Prudent reserve management, therefore, requires keeping reserves in the pegged currency. Over time, pegging to a basket of euro and yen could lead to a more balanced system of reserve currencies that offers diversification benefits at the world scale.

4. Strategic pegging to a basket should not be confused with the choice of the best reserve currency. The dominance of the US dollar as the internationally accepted reserve asset has contributed to the Global Financial Crisis, because excess liquidity in the United States has blown up asset prices and pulled down the rest of the world into the abyss. ${ }^{19}$ The Triffin Dilemma has described the contradiction between a reserve currency country's national interests and international obligations. After the Global Financial Crisis, times may have become more conducive for a reform of the global reserve regime. However, there is no point of swapping the Triffin Dilemma from the dollar to the euro. The way ahead must be an international reserve currency. The euro-yen basket could contribute to this development. In this context, the idea of the Chinese central bank governor Zhou Xiaohuan (2009) is of interest. He has suggested promoting actively the use of the SDR in international trade, commodities pricing, investment and corporate book-keeping. This could be useful for more balanced reserve management. Nevertheless, using SDRs today as the reference for exchange pegging is not recommendable. The composition of SDRs, even if expanded as proposed by Zhou, does not allow the pursuit of competitive exchange rate strategy, which has been the basis of China's success. ${ }^{20}$ However, as the catch-up growth process advances in China and Asia and the US economy adjusts to internal balance, the basket should be gradually broadened to include other currencies, including the USD, until it will effectively coincide with a reformed version of SDRs.

5. Finally, monetary cooperation between Europe and Asia must find an institutional foundation. Organizing monetary cooperation with Asia goes beyond purely bilateral or regional relations. The strategic interests of Europe, Asia, America and the rest of the world are also affected. These policy decisions must therefore be debated in the G20. However, this is a large and already fairly bureaucratic institution, where practical decision-making is tedious - witness financial regulation.

\footnotetext{
${ }^{19}$ A similar liquidity spill by the United States in the 1969s contributed to the collapse of the Bretton Woods system and the "Great Inflation". Because of the increased elasticity of labour supply, excess liquidity caused the asset inflation in the 2000 s, and not consumer price inflation.

${ }^{20}$ For the underlying theoretical argument why basket pegs are suboptimal compared to straight pegs to large currencies, see Collignon, 1999.
} 
One could therefore imagine a lead group of Euro Area, Japan, China and USA, a G4 within the G20, that would assume a pilot function for working out details of the reform. Monetary cooperation between Europe and East Asian central banks can also find an appropriate forum in ASEM (the Asia-Europe Meeting).

\section{Conclusion: Who's interest is it, anyhow?}

This paper has argued that global imbalances exist and that they are a double edged sword: they have enabled the integration of China and Asia into the world economy through rapid export-led growth, but they have also fuelled the asset bubble, which, when it burst, put the world into its deepest recession for over 70 years. However, if carefully handled, even a double-edged sword can be put to beneficial use. Thus, Asia's catch-up process must not be prematurely interrupted and Asia's economic regional integration must continue. A modest form of global imbalances would serve this purpose, provided the burden of adjustment and the absorption of Chinese surpluses are more equally shared between the USA, Japan and Europe.

It may appear that the reform proposal advanced in this paper would benefit only Asia, which will speed ahead with accelerated growth, while Europe is lagging behind, afraid of its own weaknesses, "disloyal" competition, and "social dumping". Such conclusion would be misleading. First of all, exports depend not only on relative prices, but also on demand from importing economies. CER (2010) has shown that trade with China responds significantly more strongly to changes in economic growth than to changes in the nominal exchange rate. A $10 \%$ increase in China's growth rate (approximately equivalent to a 1 percentage point increase in GDP) would raise bilateral exports by $28.8 \%$, while a $10 \%$ appreciation of the euro against the yuan lowers exports by $6.7 \%$. The effect of domestic demand in the Euro Area on imports from China is even stronger. Hence, if Europe and the United States pressured China to change the exchange regime in ways that affect economic growth in China negatively, Europe would suffer more than it would gain. It is in the European interest to create jobs at home by supporting China and Asia to pursue their dynamic growth.

Secondly, the industrial tissue will change across the world in any case, and if managed properly, this development can be welfare augmenting at the global scale. For decades Europeans have claimed that they wish poorer countries to develop; they must not turn against those who are successful, now that it is happening. Nevertheless, the distribution of welfare gains matter. Europeans, too, will benefit from more efficiently allocating resources, and wage earners would see their purchasing power improved. This is, however, no consolidation for those who are losing their jobs. Supporting Asia's development is politically only defendable, if it would generate more and better jobs that can compensate for previously lost jobs. Yet, this exactly what our reform proposal aims to achieve. Job creation depends on economic growth. The question is, whether a moderate appreciation in the euro's real exchange would on balance destroy more jobs than economic growth from more trade with Asia could generate. Any alternative exchange rate regime, whether it leaves the present system unchanged, or appreciates the yuan, or moves to a free floating exchange rate, is likely to harm Europe more, either by excessive euro strength or by a slow-down of growth in Asia. The social and political consequences for Europe could be dramatic. Unless Europe engages in a positive and 
respectful dialogue with emerging Asia and Japan, economic and political tensions in the world will increase. It is therefore in Europe's interest to play a cooperative game with China, Japan, East Asia and the United States.

\section{References}

- Anderson, J. 2008. How to think about China, Part 6; UBS Investment Research, Asian Economic Perspectives, 5. May

- Bean, Charles, 2006 Globalisation and Inflation; Bank of England Quarterly Bulletin Q4:468-475

- Bernanke, Ben S. (2005). "Remarks by Governor Ben S. Bernanke: The Global Saving Glut and the U.S. Current Account Deficit." The Sandridge Lecture, Virginia Association of Economists, Richmond, VA (March 10). URL: http://www.federalreserve.gov/boarddocs/speeches/2005/20050414/default.htm

- Borio, C. and A. Filardo, 2006. Globalisation and inflation: New cross-country evidence on the global determinants of domestic inflation; BIS Working Papers, 227.

- $\quad$ CER (Centro Europa Ricerche), Report on Europe, 2010. http://www.stefancollignon.de/PDF/CerRepport_2010.pdf

- Collignon, S. 1999. Bloc-floating and exchange rate volatility: the causes and consequences of currency blocs; in: Collignon, S. , J. Pisany-Ferry and Y. Chul Park (ed.), Exchange Rate Policies in Emerging Asian Countries, Routledge ; London, England, 1999

- Collignon, S. 2003. Monetary Stability in Europe, Routledge, London, England, 2002.

- Collignon, S. 2006. Adjusting the U.S. Current Account Deficit: What Role for the Dollar, Euro and Yen? In: Journal of Asia-Pacific Business, Vol. 7(2)

- Cooper, R. 2010. How Serious Are Global Imbalances? mimeo

- Dooley, M., D. Folkerts-Landau and P. Garber 2007. Direct Investment, Rising Real Wages, and the Absorption of Excess Labour in the Periphery; In: R. Clarida (ed), G7 Current Account Imbalances. Sustainability and Imbalances. The University of Chicago Press, Chicago and London

- Dooley M., D. Folkerts-Landau an P. Garber, 2003. An Essay On The Revived Bretton Woods System; NBER. Working Paper 9971; http://www.nber.org/papers/w9971

- Eichengreen, B. 2007. Global Imbalances and the Lessons of Bretton Woods, MIT Press

- IMF, 2009. World Economic Outlook: Washington DC.

- Kawai, M. 2010. Global Rebalancing: An Asian Perspective; mimeo

- Lane, Ph. and G. Milesi-Ferretti, 2007. A Global Perspective on External Positions. In: R. Clarida (ed), G7 Current Account Imbalances. Sustainability and Imbalances. The University of Chicago Press, Chicago and London

- Lewis, Arthur. 1954. "Economic Development with Unlimited Supplies of Labor." Manchester School of Economic and Social Studies 22(2):139-91.

- Obstfeld, M. 2005. "America's Deficit, the World's Problem." Monetary and Economic Studies (Bank of Japan) 23 (October): 25-35.

- Obstfeld, M. and K. Rogoff, 2009. "Global Imbalances and the Financial Crisis: Products of Common Causes," CEPR Discussion Papers 7606, C.E.P.R. Discussion Papers.

- Rodrik, Dani. 1986. 'Disequilibrium' Exchange Rates as Industrialization Policy; Journal of Development Economics 23: 89-106.

- Tootell, G. 1998. "Globalisation and US inflation”, Federal Reserve Bank of Boston New England Economic Review, July/August.

- Zhou Xiaochuan, 2009. Reform the International Monetary System; http://www.pbc.gov.cn/english/detail.asp?col=6500\&id=178 